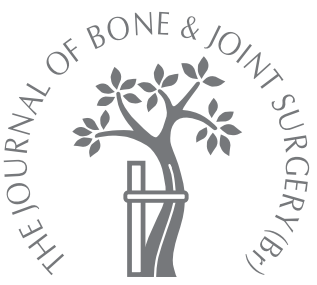

\title{
Subsidence of the stem after impaction bone grafting for revision hip replacement using irradiated bone
}

M. Hassaballa, S. Mehendale, S. Poniatowski, G. Kalantzis, E. Smith, I. D. Learmonth

From University of Bristol, Bristol, England
M. Hassaballa, MCH Ortho, MD Ortho, Senior Fellow - S. Mehendale, FRCS, FRCS Ortho, Specialist Registrar S. Poniatowski, BSc(Hons), National Tissue Bank Manager G. Kalantzis, MBBCH, Senior House Officer

E. Smith, FRCS, Consultant Orthopaedic Surgeon I. D. Learmonth, FRCS Professor of Orthopaedic Surgery

Avon Orthopaedic Centre, Southmead Hospital, Westbury on Trym, Bristol BS10 9NB United Kingdom

Correspondence should be sent to $\mathrm{Mr}$ M. Hassaballa; e-mail: mahassaballa@aol.com

(C)2009 British Editorial Society of Bone and Joint Surgery doi:10.1302/0301-620X.91B1. $20376 \$ 2.00$

$J$ Bone Joint Surg $[\mathrm{Br}]$ 2009;91-B:37-43. Received 23 October 2007; Accepted after revision 21 August 2008

Loss of bone stock is a major problem in revision surgery of the hip. Impaction bone grafting of the femur is frequently used when dealing with deficient bone stock. In this retrospective study a consecutive series of 68 patients (69 hips) who had revision of a hip replacement with femoral impaction grafting were reviewed. Irradiated bone allograft was used in all hips. Radiological measurement of subsidence of the stem, incorporation of the graft and remodelling was carried out and showed incorporation of the graft in 26 of 69 hips (38\%). However, there was no evidence of trabecular remodelling. Moderate subsidence of $5 \mathbf{~ m m}$ to $10 \mathrm{~mm}$ occurred in ten hips (14.5\%), and massive subsidence of $>10 \mathrm{~mm}$ in five $(7.2 \%)$.

The results of this study are less favourable than those of others describing studies of revision of the femoral stem using impaction bone grafting. The absence of the characteristic changes of graft remodelling noted in other series raises the question as to whether irradiated bone graft may be a significant factor influencing the post-operative outcome.

Loss of bone stock is an important factor in determining the outcome of revision of a total hip replacement. Impaction bone grafting is a valuable option in the management of deficiency of bone. ${ }^{1,2}$

There is a risk of transmitting bacterial, fungal, viral, prion and protozoal microbiological disease through human allografts. ${ }^{3,4}$ Donor selection and microbiological testing of donors and donations reduce the risk of such transmission. The bio-burden is reduced by aseptic collection, antibiotic soaks, and the use of ethylene dioxide or gamma irradiation to inactivate infectious agents. ${ }^{5,7}$ Irradiation may have an adverse effect on the mechanical properties of bone. ${ }^{8}$ However, Banks, Allen and Aldam ${ }^{9}$ did not identify any significant difference in their series of patients between the use of irradiated or fresh-frozen allografts at a mean follow-up of four years.

Excellent results have been reported from the centres which first described impaction bone grafting, ${ }^{10-12}$ but less favourable outcomes have been experienced in other centres. ${ }^{13-16}$

Frozen bone allografts, gamma irradiated with a minimum of $25 \mathrm{kGy}$ or $50 \mathrm{kGy}$, have been used at the Avon Orthopaedic Centre since 1993. Eldridge et $\mathrm{al}^{13}$ observed massive subsidence in a cohort of patients operated on at this centre before 1994. At that time, impaction bone grafting was recognised as a techniquedependent procedure and failures were ascribed to technical shortcomings associated with the learning curve. The bone grafts used were not scrutinised, nor were the results evaluated according to the nature or source of the graft. In this study we have assessed those patients who had revision hip surgery with femoral impaction grafting using irradiated bone graft after 1994.

\section{Materials and Methods}

We clinically and radiologically reviewed 68 patients (69 hips) who had femoral impaction bone grafting using frozen irradiated allograft between 1994 and 2001 at the Avon Orthopaedic Centre, Bristol, United Kingdom (Table I). All operations were performed or supervised by the two senior authors (ES, IDL). Irradiated graft from the femoral was used in all patients. The bone was initially supplied from Blood Services South West in Bristol from 1992/ 1993, then from the Oxford Regional Blood Transfusion Centre and, more recently, following a national reorganisation in 2000, by the National Blood and Tissue Services.

Before 1997 the bone from the Blood Services South West was irradiated to $50 \mathrm{kGy}$. Allograft subsequently obtained from the Oxford Regional Blood Transfusion Centre and Bone Bank and from National Blood and Tissue Services was irradiated to $25 \mathrm{kGy}$. A total of $25 \mathrm{kGy}$ is strong enough to kill most bacteria and viruses without damaging the structural properties of the graft. 
Table I. Number of hips/patients, gender, mean age and SD

\begin{tabular}{llll}
\hline & Male & Female & Total \\
\hline Number of hips/patients (\%) & $37 / 36(52.94)$ & $32 / 32 \quad$ (47.06) & $69 / 68$ \\
Mean age yrs (range) & $65(39$ to 88) & 63.2 (34 to 82) & $64.2(12.6)$ \\
\hline
\end{tabular}

Table II. The Endo-Klinik classification of femoral bone loss ${ }^{17}$

\begin{tabular}{ll}
\hline Grade & Definition \\
\hline I & $\begin{array}{l}\text { Radiolucent lines confined to the upper half of the cement mantle; } \\
\text { clinical signs of loosening } \\
\text { II }\end{array}$ \\
III & $\begin{array}{l}\text { Generalised radiolucent zones and endosteal erosion of the upper } \\
\text { IV }\end{array}$ \\
& $\begin{array}{l}\text { Gross destruction of the upper third of the femur with involvement } \\
\text { of the middle third, precluding the insertion of even a long- } \\
\text { stemmed prosthesis }\end{array}$ \\
\hline
\end{tabular}

Table III. Inclusion and exclusion criteria

\begin{tabular}{ll}
\hline Inclusion & Exclusion \\
\hline First revision operation & Septic revisions \\
Aseptic revisions & Peri-prosthetic fractures \\
Femoral impaction bone grafting in accordance with the Exeter technique & Structural allografts \\
Cemented stems & Cementless prosthesis \\
& $\begin{array}{l}\text { Incomplete notes and } \\
\text { radiographs }\end{array}$ \\
\hline
\end{tabular}

The patients' notes and radiographs of all 69 hips were reviewed. Operative notes and pre-operative radiographs were studied. Femoral bone loss was classified according to the Endo-Klinik classification ${ }^{17}$ (Table II). Inclusion and exclusion criteria are shown in Table III.

Post-operative radiographs were taken on the third day after surgery and at three months, six months and yearly thereafter.

The hip was exposed either through an anterolateral approach (35 hips) or a posterior approach (34 hips) in accordance with the surgeon's preference.

The principles of the operative technique were described by Gie et $\mathrm{al}^{18}$ using the Exeter impaction grafting system (Stryker, Newbury, United Kingdom). The femoral heads were stored at $-20^{\circ} \mathrm{C}$, allowed to thaw at operating room temperature $\left(23^{\circ} \mathrm{C}\right)$ and sectioned prior to being milled. A Novogamus bone mill was used to provide a chip size of around $5 \mathrm{~mm}$. The milled grafts were not defatted. Intra- and post-operative complications were recorded. The dose of radiation of the allografts used for 61 of the 69 hips was obtained from records at the National Blood and Tissue Services (London, United Kingdom). Palacos R (Schering-Plough, Welwyn Garden City, United Kingdom) was used in 63 hips and Simplex P (Stryker) in six hips. The Exeter (Stryker, United Kingdom) stem was used in 63 hips, the Elite/Elite plus (Depuy, Leeds, United Kingdom) in five and the CPS stem (Endoplus, Tuttlingen, Germany) was used in one. A customised set of cannulated broaches was used for the Elite/Elite system.

The serial post-operative radiographs were assessed for the timing, severity and progression of subsidence, evidence of loosening, trabecular remodelling, graft incorporation, cortical repair, alignment of the prosthesis, localised resorption and radiolucent lines. Serial radiographs were reviewed by two independent observers working together to assess loss of bone stock, signs of loosening, trabecular incorporation/remodelling and subsidence of the stem. A standardised anteroposterior radiograph of the pelvis showing both hips was used to calculate subsidence. The radiographs were taken with the tube at a distance of $100 \mathrm{~cm}$. The beam was centred midway between the upper border of the anterior superior iliac spine and the upper border of the symphis pubis. Loosening, graft incorporation and trabeculation were assessed on both anteroposterior and lateral radiographs.

Subsidence was measured by drawing a line on the long axis of the femur. Two further lines were drawn perpendicular to this, one through the centre of rotation of the femoral head, the other to one of three points on the femur: the top of the greater trochanter, the medial neck cut, or the top of the lesser trochanter. The point on the femur that was most clear and consistent on the consecutive radiographs was selected. Subsidence was defined as minimal $(<5 \mathrm{~mm})$, moderate $(5 \mathrm{~mm}$ to $10 \mathrm{~mm})$ or massive $(>10 \mathrm{~mm}) .{ }^{13}$ 
Table IV. Variables related to the development of subsidence. Results are presented as mean (SD) or numbers (\%)

\begin{tabular}{|c|c|c|c|}
\hline Variable & Hips showing no subsidence $(n=14)$ & Hips showing subsidence $(n=55)$ & p-value* \\
\hline Age at surgery (yrs) (range) & 59.1 (35 to 75$)$ & 65.5 (34 to 88 ) & 0.09 \\
\hline Female (\%) & $6 \quad(42.9)$ & $26 \quad(47.3)$ & 0.77 \\
\hline Left side of surgery (\%) & $7 \quad(50)$ & $26 \quad(47.3)$ & 0.86 \\
\hline \multicolumn{4}{|l|}{ Endo-Klinik class } \\
\hline 1 & $2(14.3)$ & $9(16.4)$ & 0.86 \\
\hline 2 & $5(35.7)$ & $23(41.8)$ & \\
\hline 3 & $7(50)$ & $23(41.8)$ & \\
\hline \multicolumn{4}{|l|}{ Consultant firm (\%) } \\
\hline First & $5(35.7)$ & $30(55)$ & 0.37 \\
\hline Second & $9(64.3)$ & $25(45.8)$ & \\
\hline \multicolumn{4}{|l|}{ Cement type (\%) } \\
\hline$P$ & $10(71.4)$ & $53(96.4)$ & 0.013 \\
\hline $\mathrm{S}$ & $4(28.6)$ & $2(3.6)$ & \\
\hline \multicolumn{4}{|l|}{ Revision component (\%) } \\
\hline Exeter & $12(85.7)$ & $51(92.7)$ & 0.47 \\
\hline Elite (Elite plus) & $2(14.3)$ & $3(5.5)$ & \\
\hline CPS & - & $1(1.8)$ & \\
\hline Neutral alignment (\%) & $11 \quad(78.6)$ & $43 \quad(78.2)$ & 0.98 \\
\hline Follow-up (mths) (range) & 21.1 (12 to 89$)$ & 30.3 ( 12 to 89 ) & 0.095 \\
\hline One-year follow-up (\%) & $9 \quad(64.3)$ & $51 \quad(92.7)$ & 0.005 \\
\hline
\end{tabular}

Trabecular remodelling was defined as a change in graft pattern, with the trabeculae running obliquely from the endosteal surface of the femur onto the cement. Graft incorporation was defined as any change in appearance on the post-operative radiograph short of fulfilling the criteria of remodelling. ${ }^{19}$ Cortical repair was present when a thinned-out or eroded cortex regained normal cortical structure and thickness. ${ }^{19}$

The patient's notes from the last follow-up clinic were reviewed. The level of mobility and the presence or absence of pain were recorded.

The mean follow-up was 28.4 months (12 to 89). Table I shows the gender distribution and mean age of the patients.

Statistical methods. A logistic regression analysis was used to study the timing of appearance of subsidence. All input variables were fitted in a Cox regression model to assess their effect on subsidence. The 'subsidence progression rate' was used to correlate the level of subsidence in millimetres $(\mathrm{mm})$ with the total period of follow-up. The differences in the level of increase of subsidence among all hips were analysed using analysis of variance (ANOVA). The level of significance was taken at $\mathrm{p}<0.05$.

\section{Results}

On radiological evaluation 11 hips (16\%) had relatively mild deficiency of bone stock (Endo-Klinik grade I), $28(41 \%)$ grade II and $30(43 \%)$ grade III. None showed grade IV deficiency.
No hips showed localised resorption. Cortical repair was present in $21(30 \%)$ and evidence of trabecular incorporation was seen in $26(38 \%)$, in 13 at six months and in 13 after oneyear. There was no evidence of remodelling in any hip in the serial follow-up radiographs.

At the time of final follow-up, 14 hips $(20 \%)$ showed no subsidence, whereas the remaining $55(80 \%)$ exhibited a varying degree of subsidence at the bone cement interface (Table IV). When first recorded at three months postoperatively, subsidence was mild in 48 hips $(70 \%)$, moderate in five (7\%) (Fig. 1) and massive in two (3\%) (Fig. 2). At final follow-up moderate subsidence $(5 \mathrm{~mm}$ to $10 \mathrm{~mm}$ ) occurred in ten cases and massive subsidence $(14.5 \%)$ occurred in five cases $(7.2 \%)$.

Variables with a p-value $<0.1$ in simple analysis (Table V) were introduced into a logistic regression model, which showed that a higher Endo-Klinik class was the only independent predictor for the early appearance of subsidence during the first three months after surgery, compared with its appearance at one year or later after operation $(\mathrm{p}=0.042)$. Stepwise regression analysis suggested that significant early subsidence and an advanced Endo-Klinik classification were independent predictors for progression of subsidence. There was a trend towards greater subsidence with a higher dose of graft irradiation, although this was not statistically significant. However, massive subsidence was only seen in patients who had received allografts irradiated to $50 \mathrm{kGy}$.

All the patients with massive subsidence had symptoms and were subsequently revised. Two complained of pain and three 


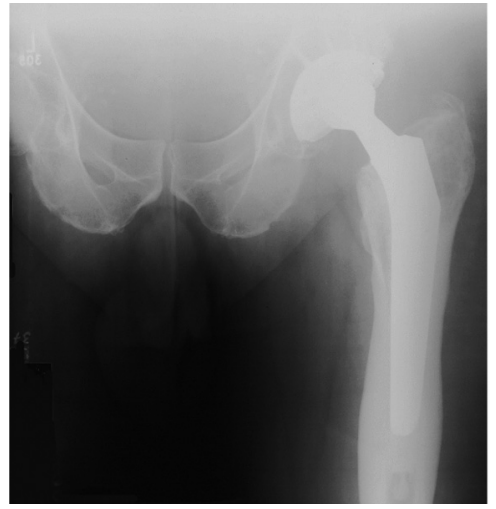

Fig. 1a

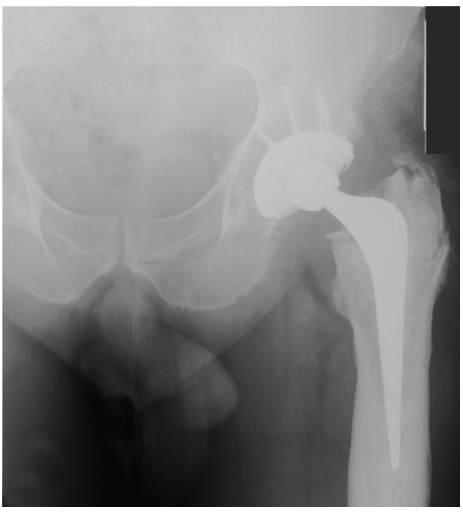

Fig. 1b

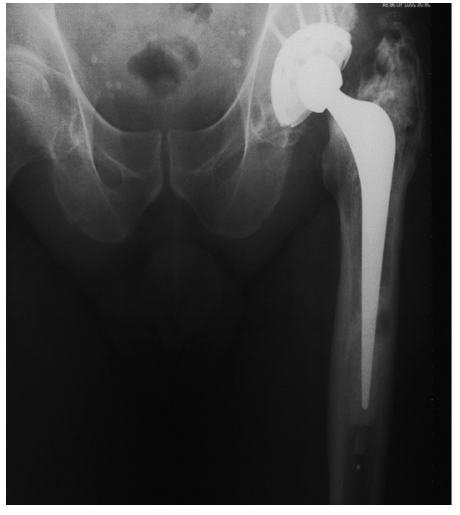

Fig. 1c

Radiographs of case 2 showing moderate subsidence a) Pre-operatively, b) immediately after operation, and c) final subsidence. Subsidence was measured by drawing a line on the long axis of the femur. Two further lines were drawn perpendicular to it, one through the centre of rotation of the femoral head, the other to one of the three points on the femur; the top of the greater trochanter, the medial neck cut or the top of the lesser trochanter. The point on the femur was selected that was most clear and consistent on the consecutive radiographs.

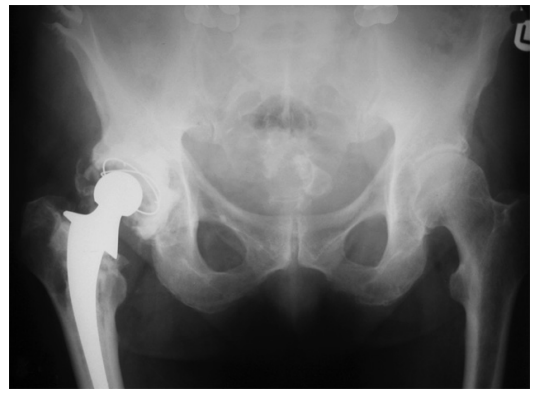

Fig. 2a

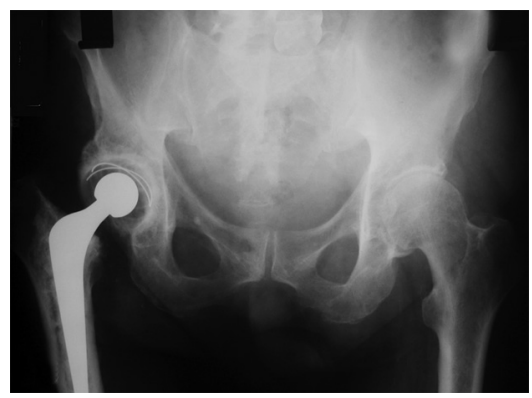

Fig. 2c

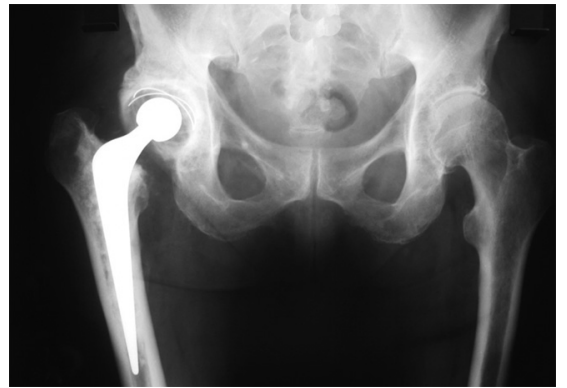

Fig. 2b

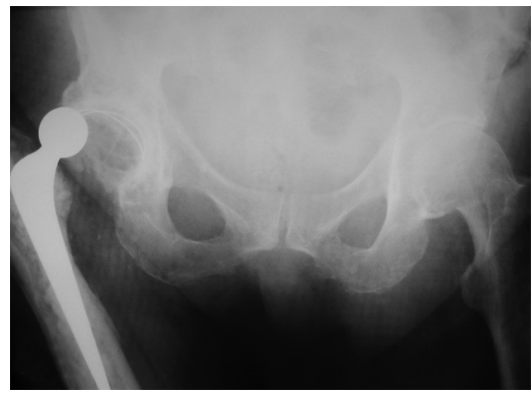

Fig. 2d

Radiographs showing massive subsidence. a) Pre-operatively, b) immediately after operation, c) one year after operation and d) final subsidence and dislocation.

of instability and symptoms of impingement. In the moderate subsidence group four patients had mild trochanteric pain; otherwise all the remaining hips were asymptomatic.

The dose of irradiation used to sterilise the allograft could be established in 61 of the 69 hips reviewed and was correlated with the measured level of subsidence of the stem. The results are shown in Table VI. Massive subsidence (Fig. 2) was encountered only in patients who had received allograft irriadiated to $50 \mathrm{kGy}$.

\section{Discussion}

Irradiation. Bone banks are struggling to meet the demand for allograft in orthopaedic surgery. The danger of contaminated allograft taken from live donors at the time of surgery is well documented. ${ }^{20}$ The use of fresh-frozen allograft bone carries with it the risk of transmission of disease. There have been a small number of cases reported in the United States where the human immunodeficiency virus (HIV) has been transmitted via allograft bone. ${ }^{21}$ This 
Table V. Variables related to the timing of initial subsidence appearance. Results are presented as mean (SD) or numbers

\begin{tabular}{|c|c|c|c|}
\hline Variable & $\begin{array}{l}\text { Hips showing subsidence at } 3 \text { months } \\
(n=43)\end{array}$ & $\begin{array}{l}\text { Hips showing subsidence at one year or later } \\
(n=12)\end{array}$ & p-value ${ }^{*}$ \\
\hline Age at surgery (yrs) (range) & 65.9 (34 to 88$)$ & 63.8 (34 to 62 ) & 0.59 \\
\hline Female (\%) & $21 \quad(48.4)$ & $5 \quad(41.7)$ & 0.75 \\
\hline \multicolumn{4}{|l|}{ Endo-Klinik class (\%) } \\
\hline 1 & $7(16.3)$ & $2(16.7)$ & \\
\hline 2 & $14(32.5)$ & $9(75)$ & \\
\hline 3 & $22(51.2)$ & $1(8.3)$ & 0.017 \\
\hline \multicolumn{4}{|l|}{ Consultant (\%) } \\
\hline First & $18(41.9)$ & $9(75)$ & \\
\hline Second & $25(58.1)$ & $3(25)$ & 0.042 \\
\hline \multicolumn{4}{|l|}{ Cement type (\%) } \\
\hline $\mathrm{P}$ & $41(95.3)$ & $12(100)$ & \\
\hline $\mathrm{S}$ & $2(4.7)$ & - & 1 \\
\hline \multicolumn{4}{|l|}{ Revision component (\%) } \\
\hline Exeter & $40(93)$ & $11(91.7)$ & \\
\hline Elite (Elite plus) & $2(4.7)$ & $1(8.3)$ & \\
\hline CPS & $1(2.3)$ & - & 0.77 \\
\hline Neutral alignment (\%) & $35 \quad(81.4)$ & $(66.7)$ & 0.43 \\
\hline Follow-up (mths) (SD) & $29.9(16.6)$ & $31.5(22.5)$ & 0.79 \\
\hline
\end{tabular}

Table VI. Dose of allograft irradiation and their subsidence category in 61 of the 69 hips in which the irradiation dose was established

\begin{tabular}{llclcr}
\hline & \multicolumn{2}{l}{ Subsidence } & & \\
\cline { 2 - 5 } & Massive & Moderate & Mild & No Total \\
\hline $50 \mathrm{kGy}$ & 4 & 6 & 17 & 8 & 35 \\
$25 \mathrm{kGy}$ & 0 & 4 & 16 & 6 & 26 \\
Total & 4 & 10 & 33 & 14 & 61 \\
\hline
\end{tabular}

virus is known to reside within the bone and remains active after gamma irradiation, although irradiation is one of the most popular methods of sterilising bone. ${ }^{22-24}$ Several authors have described the radiosensitivity of HIV. ${ }^{8,25-29}$

Currently, the National Blood and Tissue Services uses gamma irradiation to a minimum of $25 \mathrm{kGy} .{ }^{30}$ A total of $25 \mathrm{kGy}(\mathrm{SD} 5)$ is sufficient to reduce the surviving fraction of most bacteria to $10^{-9}$ but this is not adequate for HIV. However, studies have demonstrated that high doses of irradiation $\left(50 \mathrm{kGy}^{31}\right.$ or $\left.60 \mathrm{kGy}^{8}\right)$ have a deleterious effect on the mechanical properties of bone, and sterilisation of all bone by irradiation to $25 \mathrm{kGy}$ has been recommended. ${ }^{18}$

Some studies have suggested that, whereas the elastic modulus is unaffected, the ultimate stress, strain and toughness are significantly reduced as a result of sterilisation by irradiation. ${ }^{8,32-34}$ Komender, Malczewska and Komender ${ }^{35}$ showed a marked reduction in the strength of irriadiated bone as the dose increased from $30 \mathrm{kGy}$ to $60 \mathrm{kGy}$.

Radiological appearance. There has been considerable interest in the radiological appearance of impaction bone grafting and its correlation to histology. Trabecular remodelling and cortical repair were found to be consistently associated with histological evidence of bone healing in the graft. ${ }^{36}$ The radiological appearance of graft incorporation was associated with variable histology, ranging from a stable fibrous composite to an absence of any interface between graft and host bone. ${ }^{36}$

In this series, graft incorporation was found in 26 of 69 hips $(38 \%)$, whereas cortical repair was seen in $21(30 \%)$. Trabecular remodelling was not observed in any hip. These results contrast with the very high rate of remodelling reported in the series from Exeter, which showed cortical healing in $87 \%{ }^{33}$ and $89 \% .^{37}$ The use of irradiated bone in the present series might account for this difference. Holt, Elson and Ibbotson ${ }^{38}$ comparing the use of fresh-frozen and irradiated allograft bone for impaction bone grafting of the acetabulum, showed no significant difference in the clinical or radiological outcome using these different types of graft. Deakin and Bannister ${ }^{39}$ have shown that the addition of autologous marrow significantly increases the radiological evidence of graft incorporation. 


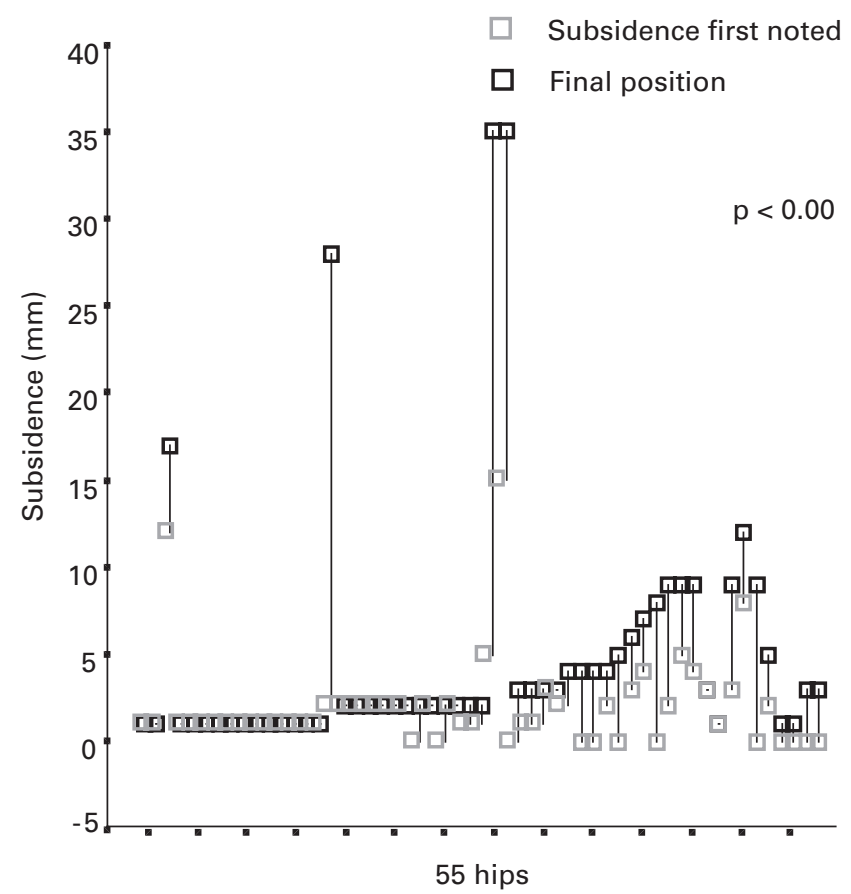

Fig. 3

Graph showing subsidence change during follow-up.

In this series, the majority of the hips that underwent moderate and massive subsidence used allograft bone which had received a higher dose of irradiation (Table VI).

Subsidence. The polished Exeter universal stem used in the majority of the hips in this series is a force-closed or taperslip $^{40,41}$ design. Such a design has been shown to migrate axially within the cement mantle more than any other stem studied, ${ }^{42}$ but there is no associated migration between cement and bone when the mantle remains intact. ${ }^{43-45}$ When the subsidence is excessive the cement mantle is disrupted and predisposes to progressive subsidence and failure.

In this series, all five hips with massive subsidence were symptomatic and underwent a further revision. The symptoms ranged from pain to impingement and dislocation. Moderate subsidence occurred in ten hips within the first two years, but the stem stabilised thereafter. None of these patients were significantly symptomatic.

Four patients had trochanteric pain unrelated to the degree of subsidence. None of the patients who showed mild subsidence were symptomatic. Minimal subsidence is almost a prerequisite to epitomise the advantages in stress distribution and fixation offered by this type of stem.

We did not find any correlation between the type of stem design used and the subsidence, but this may be related to the limited number of other stems used.

Subsidence usually occurred in the first year after operation (Fig. 3). An advanced Endo-Klinik grade was found to be an independent predictor for the appearance of subsidence as early as the third month after operation. No additional hips showed signs of subsidence after the first year, and there was no progression of subsidence after the second year.

Simplex P cement was used in less than $10 \%$ of the patients reviewed. Only $33 \%$ of stems subsided when Simplex P cement was used, compared with $84 \%$ when Palacos R cement was used. The numbers were too small for statistical significance or further comment.

Recently, Halliday et $\mathrm{al}^{10}$ suggested that the most important predictor for subsidence was the surgical technique, and that subsidence could be reduced by the use of larger bone chips in capacious canals, tighter compaction of these chips, and the use of longer stems. This is clearly a technique-dependent procedure, and numerous variables may influence the outcome.

In this series, one of the senior authors (ES) was trained in this technique at Exeter, and there was no significant difference in the operative technique between the two surgical firms. There was no statistically significant difference in the EndoKlinik stage, the results, the degree of subsidence or the case mix of patients revised by either surgical team.

Four of the five patients who showed massive subsidence had a mean age of 75.8 years (68 to 88 ; SD 9), which was significantly older than the mean age for the whole group (63.5 years (34 to 88 ; SD 12.5)). This suggests that it may be prudent to avoid the use of impaction bone grafting in elderly patients, a view supported by Halliday et al, ${ }^{10}$ who advocate its use in younger patients.

The bone chips used in this series were not defatted. Some authors believe that defatting may be significant as it can improve initial implant stability ${ }^{46}$ and the grading of the bone graft, ${ }^{47}$ thereby facilitating a more rapid incorporation. Similarly, defatting also reduced the immunogenic properties of the graft and hence the immunological response. ${ }^{48}$

This paper highlights the numerous variables that influence the outcome of impaction bone grafting, including the effects of irradiated bone graft, implant and patient variables. The degree of bone loss and the level of irradiation of the allograft appeared to be the two most important variables associated with a poor outcome.

Although a randomised controlled trial would be the ideal model to assess the influence of one specific variable on outcome, it would be difficult to match all the other potential variables in order to validate the outcome.

Impaction grafting remains a valuable option in restoring bone stock at revision hip surgery, but it is reasonable to be vigilant concerning the use of irradiated bone in these circumstances.

The authors would like to thank Mr A. Sood for assistance with artwork in this study.

No benefits in any form have been received or will be received from a commercial party related directly or indirectly to the subject of this article.

\section{References}

1. Delloye C, Cornu O, Druez V, Barbier O. Bone allografts: what they can offer and what they cannot. J Bone Joint Surg [Br] 2007;89-B:574-80.

2. Board TN, Rooney P, Kearney JN, Kay PR. Impaction allografting in revision total hip replacement. J Bone Joint Surg [Br] 2006;88-B:852-7. 
3. Tomford WW. Transmission of disease through transplantation of musculoskeletal allografts. J Bone Joint Surg [Am] 1995;77-A:1742-54.

4. Lord CF, Gebhardt MC, Tomford WW, Mankin HJ. Infection in bone allografts: incidence, nature, and treatment. J Bone Joint Surg [Am] 1988;70-A:369-76.

5. Eastland D. Infectious disease transmission through cell, tissue and organ transplantation: reducing the risk through donor selection. Cell Transplantation 1995;4:455-77.

6. Conrad EU, Gretch DR, Obermeyer KR, et al. Transmission of the hepatitus- $C$ virus by tissue transplantation. J Bone Joint Surg [Am] 1995;77-A:214-24.

7. Cieslak PR HK, Thomas AR. Hepatitis $C$ virus transmission from an antibody negative organ and tissue donor: United States 2000-2002. Morbidity and Mortality Weekly Report 2003;52:273-6

8. Currey JD, Foreman J, Laketic $\mathbf{I}$, et al. Effects of ionizing radiation on the mechanical properties of human bone. J Orthop Res 1997;15:111-17.

9. Banks MJK, Allen PW, Aldam CH. Results of impaction grafting in revision hip arthroplasty at two to seven years using fresh and irradiated allografts bone. Hip International 2003;13:1-11.

10. Halliday BR, English HW, Timperley AJ, Gie GA, Ling RS. Femoral impaction grafting with cement in revision total hip replacement: evolution of the technique and results. J Bone Joint Surg [Br] 2003;85-B:809-17.

11. English H, Timperley AJ, Dunlop D, Gie G. Impaction grafting of the femur in twostage revision for infected total hip replacement. J Bone Joint Surg $[\mathrm{Br}] 2002 ; 84$ B:700-5.

12. Schreurs BW, Arts J, Verdonschot $\mathbf{N}$, et al. Femoral component revision with the use of impaction bone grafting and a cemented polished stem: surgical technique. $J$ Bone Joint Surg [Am] 2006;88-A(Suppl 1):259-74.

13. Eldridge JD, Smith EJ, Hubble MJ, Whitehouse SL, Learmonth ID. Massive early subsidence following femoral impaction grafting. J Arthroplasty 1997;12:535-40.

14. Pekkarinen J, Alho A, Lepisto J, et al. Impaction bone grafting in revision hip surgery: a high incidence of complications. J Bone Joint Surg [Br]2000;82-B:103-7.

15. Masterson EL, Masri BA, Duncan CP. The cement mantle in the Exeter impaction allografting technique: a cause for concern. J Arthroplasty 1997;12:759-64.

16. Frances A, Moro E, Cebrian J, et al. Reconstruction of bone defects with impacted allograft in femoral revision surgery. Int Orthop 2007;31:457-64

17. Engelbrecht $\mathbf{E}$, Heinert K Hrs - Endo-Klinik. Klassifikation und Behandlungsrichtlinien von Knochensubstantzverlusted bei Revisions operationen am Huftgelenkmittelfristige Ergebnisse. Primare und Revisionsalloarthroplastik. Springer-Verlag, Berlin, 1987.

18. Gie GA, Linder $\mathbf{L}$, Ling $\mathbf{R S}$, et al. Contained morselized allograft in revision total hip arthroplasty: surgical technique. Orthop Clin North Am 1993;24:717-25.

19. Gie GA, Linder L, Ling RS, et al. Impacted cancellous allografts and cement for revision total hip arthroplasty. J Bone Joint Surg [Br] 1993;75-B:14-21.

20. Sommerville SM, Johnson N, Bryve SL, Journeaux SF, Morgan DA. Contamination of banked femoralhead allograft: incidence, bacteriology and donor follow up. Aust N Z J Surg 2000;70:480-4

21. Simonds RJ, Holmberg SD, Hurwitz RL, et al. Transmission of human immunodeficiency virus type 1 from a seronegative organ and tissue donor. N Engl J Med 1992;326:726-32

22. Turner TC, Bassett CA, Pate JW, et al. Sterilization of preserved bone grafts by high-voltage cathode irradiation. J Bone Joint Surg [Am] 1956;38-A:862-84.

23. Wright RA, Trump JG. Cooperative studies in the us of ionizing radiation for sterilization and preservation of biologic tissues. International Atomic Agency 1970:107-18.

24. Hernigou P, Delepine G, Goutallier D, Julieron A. Massive allografts sterilised by irradiation: clinical results. J Bone Joint Surg [Br] 1993;75-B:904-13.

25. Spire B, Dormont D, Barre-Sinoussi F, Montagnier L, Chermann JC. Inactivation of lymphadenopathy-associated virus by heat, gamma rays, and ultraviolet light. Lancet 1985;1:188-9.
26. Kitchen AD, Mann GF, Harrison JF, Zuckerman J. Effect of gamma irradiation on human immunodeficiency virus and human coagulation proteins. Vox Sang 1989;56:223-9.

27. Conway B, Tomford W, Mankin HJ, Hirsch MS, Schooley RT. Radiosensitivity of HIV-1: potential application to sterilization of bone allografts. Aids 1991;5:608-9.

28. Conway B, Tomford W, Hirsch MS, Scholley RT, Mankin HJ. Effect of gamma irradiation on HIV-1 In bone allograft model. Trans Orthop Res Soc 1990;15:225.

29. Campbell DG, Li P, Stephenson AJ, Oakeshott RD. Sterilization of HIV by gamma irradiation: a bone allograft model. Int Orthop 1994;18:172-6.

30. No authors listed. Services UBTTT. Guidelines for Blood Transfusion Services in the United Kingdom. The Stationary Office, London 2002, Nov; Sixth Edition.

31. Sugimoto M, Takahashi S, Toguchida J, et al. Changes in bone after high-dose irradiation: biomechanics and histomorphology. J Bone Joint Surg [Br] 1991;73-B:492-7.

32. Davy DT. Biomechanical issues in bone transplantation. Orthop Clin North Am 1999;30:553-63.

33. Anderson MJ, Keyak JH, Skinner HB. Compressive mechanical properties of human cancellous bone after gamma irradiation. J Bone Joint Surg [Am] 1991;74A:747-52.

34. Bright RW, Burchardt H. The biomechanical properties of preserved bone grafts: osteochondral allografts: biology, banking and clinical applications. 1984.

35. Komender J, Malczewska H, Komender A. Bone banking for transplantation in orthopaedic reconstructions. Ann Transplant 1996;1:70-2.

36. Linder L. Cancellous impaction grafting in the human femur: histological and radiographic observations in 6 autopsy femurs and 8 biopsies. Acta Orthop Scand 2000;71:543-52

37. Ling RS, Timperley AJ, Linder L. Histology of cancellous impaction grafting in the femur: a case report. J Bone Joint Surg [Br] 1993;75-B:693-6.

38. Holt GM SJ, Elson RA, Ibbotson C. A comparison of the performance of irradiated and non-irradiated bone graft in hip surgery. Hip International 2001;11-18.

39. Deakin D, Bannister G. Graft incorporation after acetabular and femoral impaction grafting with washed irradiated allograft and autologous marrow. J Arthroplasty 2007;22:89-94.

40. Huiskes R, Verdonschot N, Nivbrant B. Migration, stem shape, and surface finish in cemented total hip arthroplasty. Clin Orthop 1998;355:103-12

41. Shen G. Femoral stem fixation: an engineering interpretation of the long-term outcome of Charnley and Exeter stems. J Bone Joint Surg [Br] 1998;80-B:754-6.

42. Karrholm J, Hultmark P, Carlsson L, Malchau H. Subsidence of a non-polished stem in revisions of the hip using impaction allograft: evaluation with radiostereometry and dual-energy X-ray absorptiometry. J Bone Joint Surg [Br] 1999;81-B:135-42.

43. Ornstein E, Atroshi I, Franzen $\mathbf{H}$, et al. Results of hip revision using the Exeter stem, impacted allograft bone, and cement. Clin Orthop 2001;389:126-33.

44. Ornstein E, Franzen $\mathbf{H}$, Johnsson R, et al. Early subsidence of the Exeter femoral stem within the cement mantle in primary arthroplasties and in revisions using impacted allografts and cement: a roentgen stereophotogrammetric analysis. Hip International 1999;9:139-43

45. van Doorn WJ, ten Have BL, van Biezen FC, et al. Migration of the femoral stem after impaction bone grafting: first results of an ongoing, randomised study of the exeter and elite plus femoral stems using radiostereometric analysis. J Bone Joint Surg [Br] 2002;84-B:825-31.

46. Hostner J, Hultmark P, Karrholm J, Malchau H, Tveit M. Impaction technique and graft treatment in revisions of the femoral component: laboratory studies and clinical validation. J Arthroplasty 2001;16:76-82.

47. Brewster NT, Gillespie WJ, Howie CR, et al. Mechanical considerations in impaction bone grafting. J Bone Joint Surg [Br] 1999;81-B:118-24.

48. Thoren K, Aspenberg P, Thorngren KG. Lipid extraction decreases the specific immunologic response to bone allografts in rabbits. Acta Orthop Scand 1993;64:44-6. 